\title{
ArcheoSciences
}

Revue d'archéométrie

\section{Gilding on wall paintings from a period}

Between the $14^{\text {th }}-16^{\text {th }}$ centuries $\mathrm{AD}$ in the Lombard lake region

La dorure sur peintures murales entre le XIV et le XVI siècles dans la région des lacs lombards

\section{Giovanni Cavallo and Marcel Verda}

\section{(2) OpenEdition}

\section{Journals}

Electronic version

URL: http://journals.openedition.org/archeosciences/2545

DOI: $10.4000 /$ archeosciences. 2545

ISBN: 978-2-7535-1598-7

ISSN: $2104-3728$

Publisher

Presses universitaires de Rennes

\section{Printed version}

Date of publication: 31 December 2009

Number of pages: $409-415$

ISBN: 978-2-7535-1181-1

ISSN: $1960-1360$

\section{Electronic reference}

Giovanni Cavallo and Marcel Verda, « Gilding on wall paintings from a period », ArcheoSciences [Online], 33 | 2009, Online since 10 December 2012, connection on 02 May 2019. URL : http://

journals.openedition.org/archeosciences/2545; DOI : 10.4000/archeosciences.2545 


\title{
Gilding on wall paintings from a period between the $14^{\text {th }}-16^{\text {th }}$ centuries AD in the Lombard lake region
}

\author{
La dorure sur peintures murales entre le XIV et le XVI siècles \\ dans la région des lacs lombards
}

\author{
Giovanni Cavallo* and Marcel Verda**
}

\begin{abstract}
The use of gildings on wall paintings enjoyed its largest development in Italy between the $13^{\text {th }}$ and $14^{\text {th }}$ centuries AD. This work covers a few important artefacts from the Lombard lake region, dating from a period between 1360 and 1520, and painted by the Seregnesi, Da Tradate and De Passeri studios. Its purpose is to understand the gilding techniques by means of scientific examinations (OM, SEM/EDS, FTIR), integrated with information from ancient treatises.

Two main gilding techniques have been used in this context: the composite foil (tin and gold), and the single gold foil, in both cases fixed on the wall by a type of oil-based adhesive with the addition of inorganic pigments, mostly lead white and ochres, called missione. The scientific results are in agreement with the recipes contained in the ancient treatises, particularly in the Libro dell'Arte by Cennino Cennini.

Extending the research to other case studies in Tessin and Italy, it is clear that the gilding technique was not influenced by the geographical and historical context, but by the final appearance required by the decoration on the wall surface. The use of tin in the composite foil permitted the gold foil to be burnished and engraved.
\end{abstract}

Résumé : L'emploi de la dorure sur des peintures murales en Italie a eu son apogée entre le XIIT et le XIV siècle. Ce travail traite les objets peints dans la région des lacs lombards, entre 1360 et 1520, réalisés dans les ateliers des Seregnesi, des Da Tradate et d'Andrea de Passeri, en vue d'une compréhension de la technique de la dorure au moyen de techniques scientifiques (MO, MEB/EDX, FTIR) et des informations obtenues par étude des traités anciens.

Deux techniques sont principalement utilisées: la feuille composée (étain et or) et la simple feuille d'or; dans les deux cas les feuilles sont fixées à la surface avec un adhésif huileux auquel sont ajoutés des pigments inorganiques, le plus souvent du blanc de plomb et des ocres, appelé missione (mixtion).

Les résultats scientifiques trouvent une bonne correspondance avec les recettes mentionnées dans les traités anciens, en particulier dans le Libro dell'Arte de Cennino Cennini.

En étendant les recherches à d'autres exemples dans le Tessin et en Italie, il paraît évident que la technique n'a pas été influencée par le contexte historique ou géographique, mais par l'aspect final de la surface murale employée. L'utilisation de l'étain dans la feuille composée permettait de brunir et graver la surface.

Keywords: gilding, gold, missione, Tessin, tin, wall paintings.

Mots-clés : dorure, or, missione (mixtion), Tessin, étain, peinture murale.

\footnotetext{
* University of Applied Sciences of Southern Switzerland, Dept. Environment, Constructions and Design, Institute of Materials and Constructions Trevano-P.O. Box 12 CH-6952 Canobbio (Tessin). (giovanni.cavallo@supsi.ch)

** Architect and Conservator - Via San Nicolao 3 CH-6816 Bissone (Tessin).
} 


\section{INTRODUCTION}

The present research was initiated during the conservation project of the wall painting representing the Crucifixion scene painted by Andrea De Passeri in 1513 in the St. Alessandro Church in Lasnigo (Lombardy, Northern Italy). Traces of the original gold foil, in the form of irregular and fragile flakes, were found on the halos of the Virgin and the adoring angels (Bonizzoni et al., 2007).

Further in-depth studies (Cavallo and Verda, 2008) revealed in detail the technique that was adopted: a composite metal foil - gold and tin, probably fixed with glue - was adhered to the surface of the wall painting by means of a type of adhesive called missione. This adhesive was a mixture of linseed oil with the addition of pigments with drying capacity, such as lead white and white bones; yellow ochres were used in small amounts.

The research was extended to the period between 1360 and 1520 in the Lombard lake region, corresponding in the past to the present day Tessin (Southern Switzerland) and Lombardy (NW Italy), when the city of Milan played a crucial historical role and became one of the most important centres of European culture. In the fourteenth century - Trecento - many famous artists, such as Giovanni di Benedetto from Como, Giovannino de' Grassi, and Balbello from Pavia, worked for religious and aristocratic clients, also supported by the miniaturists and goldsmiths gathered under the Scuola of St. Eligio. The peak of this political and cultural life took place during the government of Gian Galeazzo Visconti, who extended the control in the North-eastern and Central Italy. After his death in 1402, a period of political instability forced many artists to move principally towards Eastern Italy. The stagnant artistic situation received a renewed impulse during the reign of the Sforza dynasty in the second half of the $15^{\text {th }}$ century, and particularly under Ludovico il Moro and his wife, Beatrice d'Este, when Milan attracted important literates and artists, such as Bramante and Leonardo da Vinci. The decline of the visconteo-sforzesco government took place in 1500, when the French occupied Milan (Gregori, 1997; 1998).

Returning to our research on gildings, the examined artworks are part of the aforementioned political and cultural panorama. The attention was focused on the lunette (Fig. 1) attributed to Giovanni da Milano (1360) preserved in the Santa Maria delle Grazie Oratory at Mendrisio (Tessin), and to the cycle of wall paintings in the church of St. Carlo at Prugiasco-Negrentino (Tessin), dating from the last decade of the $15^{\text {th }}$ century, where the Antonio Da Tradate and Seregnesi studios painted the apses. The Crucifixion scene painted by Andrea De Passeri at Lasnigo (1513) is also part of this work.

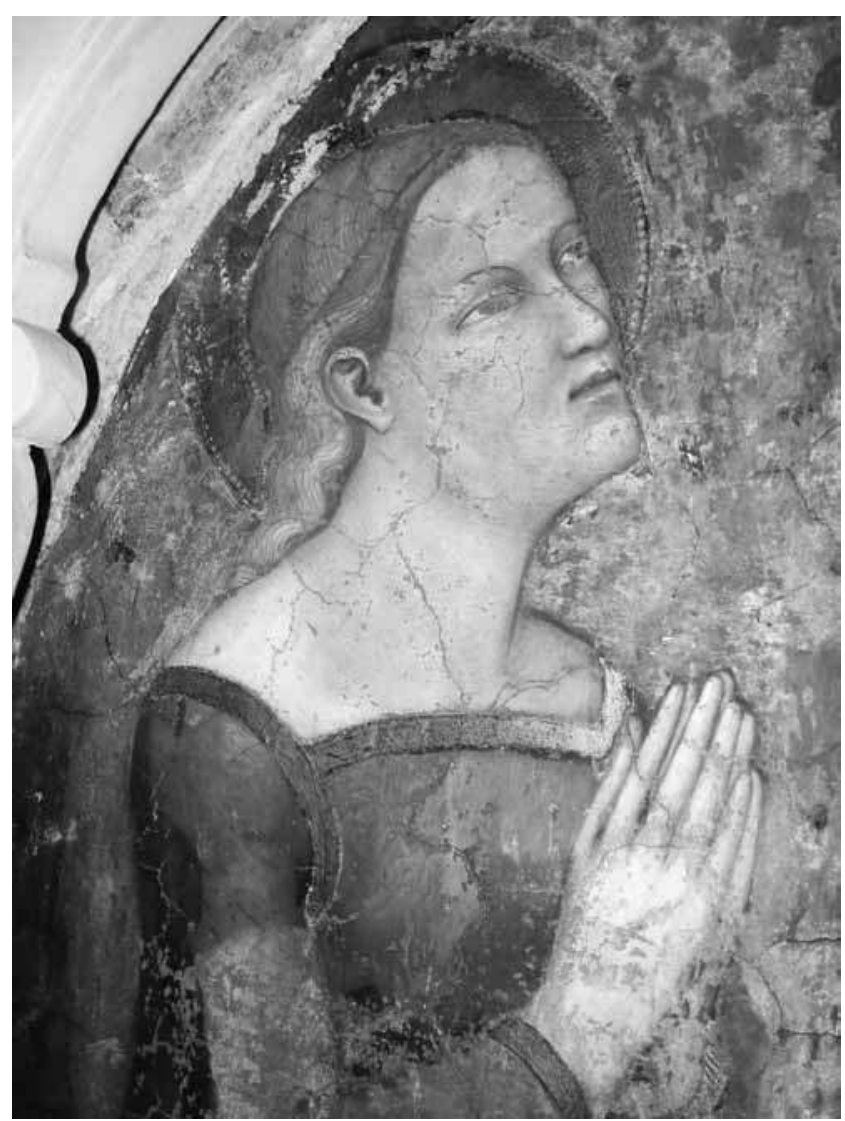

Figure 1: (See colour plate) The Oratory of Santa Maria delle Grazie (Mendrisio, Southern Switzerland). Detail of the lunette attributed to Giovanni da Milano (1360).

Figure 1 : (Voir planche couleur) Oratoire de Santa Maria delle Grazie (Mendrisio, Tessin). Détail de la lunette attribuée à Giovanni da Milano (1360).

The main goals of the research addressed the following questions: did the geographic and temporal contexts influence the gilding technique? Was the gilding technique influenced by other important studios in Italy, operating mainly in Tuscany? What kind of differences and similarities was it possible to establish with the main studios in Italy? Are there correspondences between the analytical results and the ancient recipe books? Was the identification of the original technique possible in the cases of overlapping layers, due to past restoration works?

\section{Methods}

Two approaches have been adopted in studying the gilding techniques and materials. The first entails a critical reading of the ancient recipe books and the second the scientific investigation of selected samples. 


\section{Ancient recipe books}

Ancient manuscripts report the materials and methods used for gilding. In the De Coloribus et artibus Romanorum, par. XLV (Alexander, 1967), Heraclius refers to the method used for gilding upon tin. In the Libro dell'Arte, par. XCVII (Brunello, 1971), Cennino Cennini mentions how to cut the gilt tin. De Diversis artibus by Theophilus, par. XXI (Caffaro, 2000), the Libro dell'Arte by Cennini, par. XCI and XCII (Brunello, 1971), and the Esperimenta de Coloribus by Jehan Le Begue, par. 105 (Alexander, 1967) all report indications of the methods used in attaching the metal foils (composite foil). Finally, the De Coloribus faciendis by Petrus De S. Audemar, par. 190 (Alexander, 1967) refers to the technique employed for laying the gold foil on a wall.

The interpretation of the manuscripts is difficult; the linguistic style, useful for the comprehension of the Medieval and Late Medieval outlook, is also a cause of terminological ambiguity, compromising the real interpretation of the text. An additional issue is the discontinuity of the information: some recipes are described carefully, as in the Libro dell'Arte by Cennini, others superficially.

\section{Scientific investigations}

Scientific investigations have been carried out on selected samples collected in Switzerland (Mendrisio and PrugiascoNegrentino) and Italy (Lasnigo). Optical microscopy (OM) of cross-sections in reflected light (Plester, 1956) has been used to identify the stratigraphy, and for a preliminary characterization of each layer. Scanning Electron Microscopy (SEM) coupled with an EDS detector (Vega Tescan electron microscope) has been used for the determination of the elemental composition of each layer detected under the optical microscope. The instrumental setup was $20 \mathrm{kV}$, vacuum mode $H V$, working distance $9 \mathrm{~mm}$. Infrared spectroscopy (FTIR) has been used for determining the organic (and inorganic) fraction of the samples; a Perkin Elmer Spectrum One BM working in the range 4000-600 $\mathrm{cm}^{-1}$ has been used. Table 1 reports the description of the studied samples.

\section{RESULTS}

\section{Optical microscopy (OM)}

Table 2 reports the cross-section stratigraphy (optical microscopy in incident light).

\begin{tabular}{|l|l|}
\hline Samples & Location and description \\
\hline GM1 & $\begin{array}{l}\text { Mendrisio, lunette attributed to G. da Milano. Gilding } \\
\text { fragment from the halo of St. Caterina. }\end{array}$ \\
\hline GM3b & $\begin{array}{l}\text { Mendrisio, lunette attributed to G. da Milano. Gilding } \\
\text { fragment from the halo of the Virgin. }\end{array}$ \\
\hline NE1 & $\begin{array}{l}\text { Prugiasco-Negrentino, Seregnesi's studio. Gilding } \\
\text { fragment from the halo of the Apostle. }\end{array}$ \\
\hline NE3 & $\begin{array}{l}\text { Prugiasco-Negrentino, Da Tradate's studio. Gilding } \\
\text { fragment from the halo of the Virgin Mary. }\end{array}$ \\
\hline CR9 & $\begin{array}{l}\text { Lasnigo, Andrea De Passeri. Gilding fragment from the } \\
\text { halo of the Virgin Mary. }\end{array}$ \\
\hline CR10 & $\begin{array}{l}\text { Lasnigo, Andrea De Passeri. Gilding fragment from St. } \\
\text { Alessandro's sword. }\end{array}$ \\
\hline
\end{tabular}

Table 1: Samples, location and description.

Tableau 1 : Échantillons, localisation et description.

The data show two types of gildings; the use of composite and single foil. It should be taken into account that the samples collected at Mendriso and Negrentino come from restored gildings, while the one in Lasnigo is the original gilding. However, the stratigraphy corresponding to the sample NE1 (Fig. 2) contains information both on the original technique and the restored one.

\section{Infrared Spectroscopy (FTIR)}

Infrared Spectroscopy has been used for understanding the composition of the adhesive applied to attach the metal foil or the composite foil on the wall. All the examined samples show the presence of C-H absorption bands at 2918, 2845, 1736, 1460 and $1402 \mathrm{~cm}^{-1}, \mathrm{C}-\mathrm{O}$ at 1243 and 1100 $\mathrm{cm}^{-1}$, and C-C at $723 \mathrm{~cm}^{-1}$, characteristic of linseed oil. Calcium carbonates show the characteristic bands at 1410 , 873 and $712 \mathrm{~cm}^{-1}$; the presence of white lead is confirmed by the absorption bands at 3533,1046, $681 \mathrm{~cm}^{-1}$. Traces of calcium oxalates (samples CRs) are marked by the characteristic absorption at $1320 \mathrm{~cm}^{-1}$.

The reported data are in accordance with the use of missione, a type of adhesive made with linseed oil and pigments with drying capacity. Ca-oxalates could be referred to the mineralization of the animal glue used to attach the two metal foils.

\section{Microanalysis (SEM/EDS)}

Microanalysis has been carried out on each layer detected by OM, with the exclusion of the support layer (plaster, labelled 0); the results are reported in Table 3. The microanalysis clearly shows the presence of different tech- 


\begin{tabular}{|c|c|c|}
\hline Sample & Layers & Description \\
\hline \multirow{3}{*}{ GM1 } & 0 & Lime-based plaster \\
\hline & 1 & Brown layer, thickness $100 \mu \mathrm{m}$. \\
\hline & 2 & Bright metal foil. \\
\hline \multirow{3}{*}{ GM3b } & 0 & Lime-based plaster \\
\hline & 1 & Brown layer, thickness $100 \mu \mathrm{m}$. \\
\hline & 2 & Bright metal foil. \\
\hline \multirow{6}{*}{ NE1 } & 0 & Lime-based plaster. \\
\hline & 1 & Brown layer, thickness $20-50 \mu \mathrm{m}$. \\
\hline & 2 & $\begin{array}{l}\text { Non continuous grey-black layer, thickness } \\
20 \mu \mathrm{m} \text {. }\end{array}$ \\
\hline & 3 & Red layer, thickness $30 \mu \mathrm{m}$. \\
\hline & 4 & Bright metal foil. \\
\hline & 5 & Red layer, thickness $30 \mu \mathrm{m}$. \\
\hline \multirow{3}{*}{ NE3 } & 0 & Lime-based plaster. \\
\hline & 1 & Yellow to brownish layer, thickness $100 \mu \mathrm{m}$. \\
\hline & 2 & Bright metal foil. \\
\hline \multirow{3}{*}{ CR9 } & 1 & Brownish layer, thickness $100 \mu \mathrm{m}$. \\
\hline & 2 & Grey-black layer, thickness $20 \mu \mathrm{m}$. \\
\hline & 3 & Irregular traces of a bright metal foil. \\
\hline \multirow{4}{*}{ CR10 } & 0 & Lime-based plaster. \\
\hline & 1 & Brownish layer, thickness $100 \mu \mathrm{m}$. \\
\hline & 2 & Grey-black layer, thickness $20 \mu \mathrm{m}$. \\
\hline & 3 & Irregular traces of a bright metal foil. \\
\hline
\end{tabular}

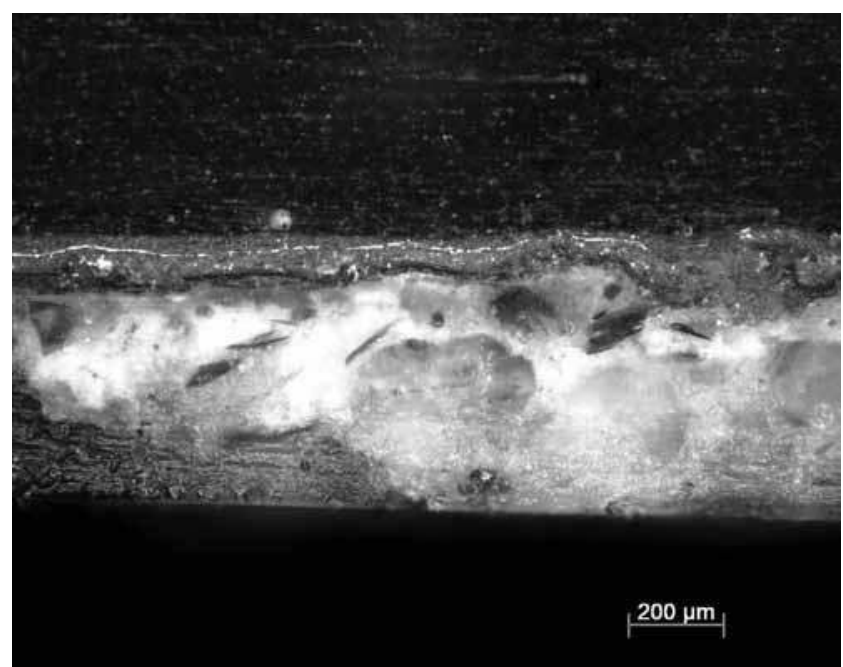

Figure 2: (See colour plate) Sample NE1: cross-section. Figure 2: (Voir planche couleur) Échantillon NE1: coupe transversale.

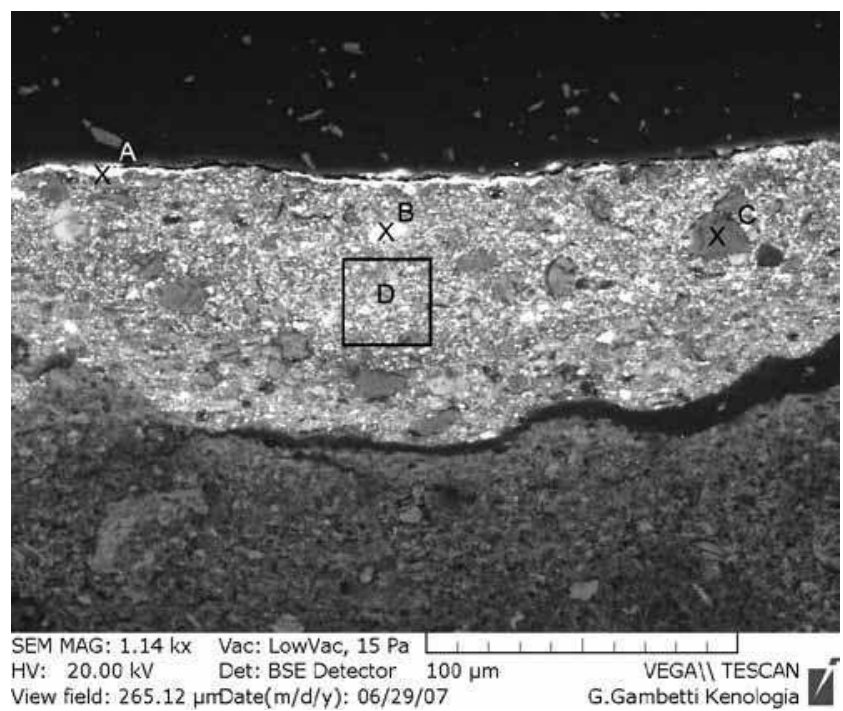

Figure 3: Sample GM3b: BSE picture with indication of the investigated areas.

Figure 3 : Échantillon GM3b : image BSE avec indication de la surface étudiée.

$(\mathrm{Cu}+\mathrm{Zn}+\mathrm{Fe})$, with thickness ranging from 1.0 to $4.5 \mu \mathrm{m}$, was applied on the bole (aluminium silicate). A later restoration work shows the use of gold with a thickness around $1.30 \mu \mathrm{m}$ on a new layer of bole.

\section{Discussion AND CONCLUSION}

The analytical data, integrated with information from the ancient manuscripts and other case studies referred in the 


\begin{tabular}{|c|c|c|c|c|c|c|c|c|c|c|c|c|c|}
\hline \multirow{2}{*}{ Sample } & \multirow{2}{*}{ Layer } & \multicolumn{12}{|c|}{ Chemical elemental composition } \\
\hline & & $\mathrm{Ca}$ & $\mathrm{Mg}$ & $\mathrm{Al}$ & $\mathrm{Si}$ & $\mathrm{Pb}$ & $\mathrm{Fe}$ & $\mathrm{Cu}$ & $\mathrm{Au}$ & $\mathrm{Ag}$ & Sn & $\mathrm{Zn}$ & $\mathrm{P}$ \\
\hline \multirow{2}{*}{ GM1 } & 1 & $\operatorname{tr}$ & $\operatorname{tr}$ & $\operatorname{tr}$ & + & +++ & $\operatorname{tr}$ & $\operatorname{tr}$ & - & - & - & - & - \\
\hline & 2 & - & $\operatorname{tr}$ & $\operatorname{tr}$ & - & - & $\operatorname{tr}$ & $\operatorname{tr}$ & +++ & $\operatorname{tr}$ & - & - & - \\
\hline \multirow{2}{*}{ GM3b } & 1 & + & $\operatorname{tr}$ & $\operatorname{tr}$ & + & +++ & + & - & - & - & - & - & - \\
\hline & 2 & $\operatorname{tr}$ & $\operatorname{tr}$ & $\operatorname{tr}$ & $\operatorname{tr}$ & - & $\operatorname{tr}$ & $\mathrm{tr}$ & +++ & - & - & - & - \\
\hline \multirow{5}{*}{ NE1 } & 2 & - & - & - & - & - & - & - & - & - & +++ & - & - \\
\hline & 3 & + & - & + & +++ & - & $\operatorname{tr}$ & - & - & - & - & - & - \\
\hline & 4 & - & - & - & - & - & $\mathrm{tr}$ & +++ & - & - & - & ++ & - \\
\hline & 5 & + & - & + & +++ & - & $\operatorname{tr}$ & - & - & - & - & - & - \\
\hline & 6 & - & - & - & - & - & - & - & +++ & - & - & - & - \\
\hline \multirow{2}{*}{ NE3 } & 1 & +++ & - & - & $\operatorname{tr}$ & +++ & $\operatorname{tr}$ & - & - & - & - & - & - \\
\hline & 2 & - & - & - & - & - & - & - & +++ & - & - & - & - \\
\hline \multirow{3}{*}{ CR9 } & 1 & ++ & $\operatorname{tr}$ & - & $\mathrm{tr}$ & +++ & + & - & - & - & - & - & ++ \\
\hline & 2 & - & - & - & - & - & - & - & - & - & +++ & - & - \\
\hline & 3 & - & - & - & - & - & - & - & +++ & - & - & - & - \\
\hline \multirow{3}{*}{ CR10 } & 1 & ++ & $\operatorname{tr}$ & - & $\operatorname{tr}$ & +++ & + & - & - & - & - & - & ++ \\
\hline & 2 & - & - & - & - & - & - & - & - & - & +++ & - & - \\
\hline & 3 & - & - & - & - & - & - & - & +++ & - & - & - & - \\
\hline
\end{tabular}

Table 3: Qualitative chemical elemental composition of the gildings layers $(+++$ high; ++ medium; + low; tr traces).

Tableau 3 : Composition chimique élémentaire qualitative des couches des dorures $(+++$ fort $;++$ moyen; + bas; tr traces).

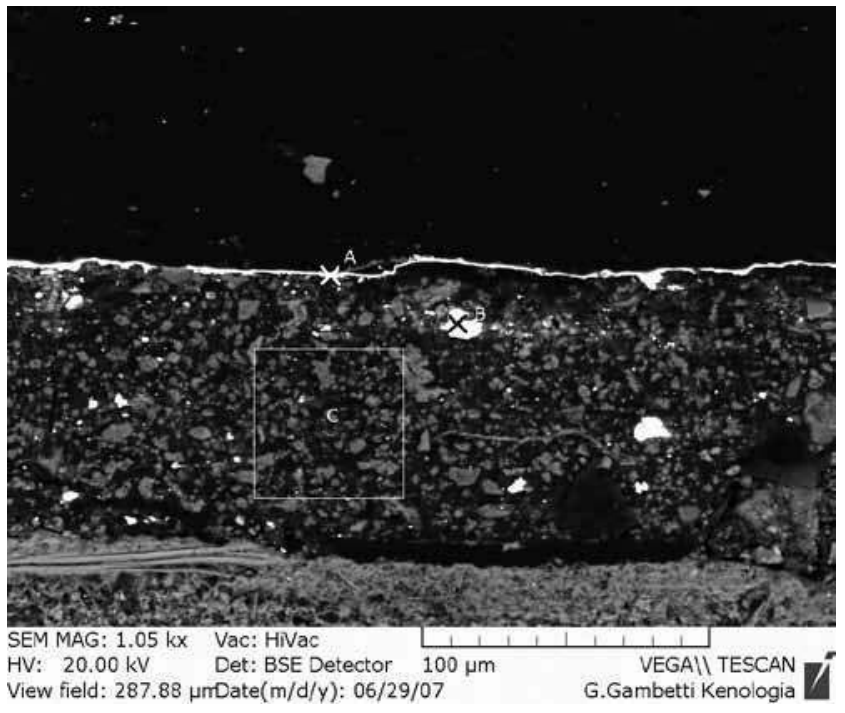

Figure 4: Sample NE3: BSE picture with indication of the investigated areas.

Figure 4 : Échantillon NE3 : image BSE avec indication de la surface étudiée.

specialist literature, allow us to define the gilding techniques in the period under consideration, between the first half of the $14^{\text {th }}$ century and the beginning of the $16^{\text {th }}$ century.

Composite foil has been used in the Crucifixion scene painted by Andrea De Passeri in Lasnigo (1513). Indications on the use of the composite foil have also been detected in the stratigraphy of the wall paintings executed by the Seregnesi in Negrentino (last decade of the $15^{\text {th }}$ century), where the tin foil is applied on the oil-based missione. We may suggest that the gold, or another precious metal such as silver, fell down because of the loss in binding power of the animal glue between the gold and the tin; according to Matteini and Moles (1990), the thickness of the animal glue was of the order of a few microns. Other famous cases in the same area are the Teodolinda Chapel in the St. Giovanni Battista Cathedral in Monza - Tales of the Queen Teodolinda painted by Franceschino, Gregorio and Giovanni Zavattari in 1444 (Cassanelli and Conti, 1991) - and the Baptist Tales in the Castiglione Olona Baptistery painted by Masolino da Panicale in 1435 (Marani, 1997). The use of tin is also mentioned on the Tabernacolo in via del Leone in Florence, painted in 1356 by Tommaso di Stefano, called Giottino (Matteini and Moles, 1982), the Trinità painted by Masaccio in Santa Maria Novella in Florence between 1425 and 1427, and the St. Giovanni Baptistery in Siena between 1447 and 1489.

The technological process of the composite foil applied on the wall by means of an oil-based missione is recommended by Cennino Cennini (Brunello, 1971). The use of a double metal foil is required for gold burnishing: a strong burnishing (Alexander, 1967) could produce abrasions of the gold foil, as suggested by St. Audemar; therefore, the tin foil was used to attenuate this inconvenience. According to Heraclius (Alexander, 1967), the process employed to fix 
the gold with tin was carried out on a desk, using a suitable wooden board.

The use of the single foil applied on an oil-based missione layer has been detected at Negrentino (on the works of Da Tradate's studio and on the lunette attributed to Giovanni da Milano, 1360, at Mendrisio). We should take into consideration that at these two sites, restoration works have been carried out during the middle of the $20^{\text {th }}$ century. Considering the thickness of the gold foil, its recent use appears clear; the thickness ranges between 1.20 and 1.50 $\mu \mathrm{m}$, lower than that of the gold foil in the Lasnigo church, where the metal has a thickness up to $3.00 \mu \mathrm{m}$.

Other examples of gildings with a single foil are the Passion of Christ on the chancel arch in Santa Maria delle Grazie Bellinzona, Tessin (end of the $15^{\text {th }}$ century), attributed to Foppa's studio (Moles, 1998), and in the Cathedral of Monza (Matteini and Moles, 1991).

The presence of wax mixed with resin as an adhesive for the composite foil has been detected only on the wall painting representing the Last Supper (uncertain attribution), painted around 1520 in the St. Ambrogio Church at Ponte Capriasca (Gilardi, 1993).

During the period towards the end of the $14^{\text {th }}$ century, and particularly during the $15^{\text {th }}$ century, the interest of the aristocracy was oriented towards a court sensibility; this new attitude will condition the choices of many Lombard artists invited to recreate on the walls the magical atmosphere of the illuminated manuscripts. The artists were asked to use the gold on wall paintings; they were aware of the great technical problems linked with the use of metal foils on the wall. The recipe books could play an important role for solving such problems. The actual distribution of these books is an open issue; the costs for copying were high, and sometimes the contents, moving between different fields, such as medical science and alchemy to artistic practice, coupled with the different idioms being used, and the limitations deriving from the translations, limited their accessibility to the artists. It is more probable that oral tradition was the main vehicle employed to hand down past practices, also supported by the skill achieved during training in other studios.

In conclusion, the microanalysis of selected cross-sections was very useful for the identification of the gilding technique, especially when integrated with infrared spectroscopy carried out on the adhesive layers. This qualitative information is per se sufficient for understanding the gilding technique; a quantitative approach is very important when provenance studies of the raw materials, characterizations of the compositional homogeneity versus heterogeneity of the metals, or their typological classification are fundamental issues for the research.
The authenticity of the adopted techniques is very clear for some of the investigated artefacts; the thickness of the gold foil represents a key factor for distinguishing between original and renewed gildings. The use of non-invasive analytical methods such as portable $\mu$-XRF represents a practical way for determining the thickness of the gold foil.

Furthermore, restored gildings sometimes reveal the marker of the original technique, as confirmed by the use of tin metal; in these cases, a cautious approach should be adopted during the interpretation of the analytical data.

Finally, it seems that the use of a gilding technique rather than another is not influenced either by chronology or by the regional context: the choice was depending on the final appearance of the gilding on the wall painting and the options available for processing.

\section{References}

Alexander, M. (ed.), 1967. Original treatises on the arts of painting. New York, Dover Publications.

Bonizzoni, L., Bruni, S., Gargano, M., Guglielmi, V., Ludwig, N., Moneta, A. and Milazzo, M., 2007. Indagini sugli affreschi della chiesa di S. Alessandro a Lasnigo (CO). Atti del 4. Congresso Nazionale di Archeometria, Bologna, Patron Ed., 115-127.

Brunello, F. (ed.), 1971. Il libro dell'arte di Cennino Cennini. Vicenza: Ed Neri Pozza.

Caffaro, A. (ed.), 2000. Teofilo Monaco. De diversis artibus. Salerno, Ed. Palladio.

Cassanelli R. and Conti, R., 1991. Monza, La cappella di Teodelinda nel Duomo. Milano, Ed. Electa.

Cavallo, G. and Verda, M., 2008. Historical, microanalytical evidences and limits of non-invasive technologies in studying gildings on $16^{\text {th }}$ century wall paintings, in CD Proceedings of the IX International Conference ART2008, Jerusalem.

Gregori, M., 1997. Pittura a Milano dall'Alto Medioevo al Tardogotico. Milano, Ed. Cassa di Risparmio delle Provincie Lombarde.

Gregori, M., 1998. Pittura a Milano, Rinascimento e Manierismo. Milano, Ed. Cassa di Risparmio delle Provincie Lombarde.

Gilardi, A., 1993. Ponte Capriasca. Il Cenacolo restaurato. Lugano, Ed. Fondazione H. Dietler-Kottmann.

Marani, P. C., 1997. Conservazione e valorizzazione degli affreschi nella Provincia di Varese, in Proceedings of the conference held in Varese in 1995, Provincia di Varese.

Matteini, M. and Moles, A., 1982. Tommaso di Stefano detto Giottino, Madonna col Bambino in U. Baldini (ed.), Metodo e scienza, Firenze, Ed. Sansoni. 
Matteini, M. and Moles, A., 1990. Le tecniche di doratura nella pittura murale, in C. Danti C., M. Matteini, A. Moles (eds.), Le pitture murali: tecniche, problemi, conservazione. Firenze, Ed. Centro Di, 121-126.

Matteini, M. and Moles, A., 1991. Le "Storie" di Teodelinda nel ciclo degli Zavattari: alcune indagini preliminari sulla natura dei materiali pittorici e sulla loro collocazione stratigrafica, in
R. Cassanelli, R. Conti, Monza, La cappella di Teodelinda nel Duomo. Milano, Ed. Electa, 164-171.

Moles, A., 1998. Analisi chimiche e strumentali preliminari alle prove di pulitura. 1st Report. Bellinzona, Ufficio Beni Culturali.

Plester, J., 1956. Cross-section and chemical analyses of paint samples, Studies in Conservation 2: 110-157. 
